UDC 519.23

doi: https://doi.org/10.20998/2522-9052.2021.4.11

Lev Raskin ${ }^{1}$, Larysa Sukhomlyn ${ }^{2}$, Dmytro Sagaidachny ${ }^{1}$, Roman Korsun ${ }^{1}$

${ }^{1}$ National Technical University "Kharkiv Polytechnic Institute", Kharkiv, Ukraine

${ }^{2}$ Kremenchuk Mikhail Ostrogradskiy National University, Kremenchuk, Ukraine

\title{
ANALYSIS OF MULTI-THREADED MARKOV SYSTEMS
}

\begin{abstract}
Known technologies for analyzing Markov systems use a well-operating mathematical apparatus based on the computational implementation of the fundamental Markov property. Herewith the resulting systems of linear algebraic equations are easily solved numerically. Moreover, when solving lots of practical problems, this numerical solution is insufficient. For instance, both in problems of structural and parametric synthesis of systems, as well as in control problems. These problems require to obtain analytical relations describing the dependences of probability values of states of the analyzed system with the numerical values of its parameters. The complexity of the analytical solution of the related systems of linear algebraic equations increases rapidly along with the increase in the system dimensionality. This very phenomenon manifests itself especially demonstratively when analyzing multi-threaded queuing systems. Accordingly, the objective of this paper is to develop an effective computational method for obtaining analytical relations that allow to analyze high-dimensional Markov systems. To analyze such systems this paper provides for a decomposition method based on the idea of phase enlargement of system states. The proposed and substantiated method allows to obtain analytical relations for calculating the distribution of Markov system states. The method can be effectively applied to solve problems of analysis and management in high-dimensional Markov systems. An example has been considered.
\end{abstract}

Keywords : multi-threaded queuing systems; high dimensionality; decomposition method of states enlargement.

\section{Introduction}

The conventional technology to analyze Markov systems provides for calculating the limit vector of probabilities of system states [1-5] using a formula

$$
\pi=\pi W,
$$

$\pi=\left(\pi_{1}, \pi_{2}, \ldots, \pi_{n}\right)-$ is the vector of probabilities of states, $W=\left(P_{i j}\right)$ - is a matrix of probabilities of transition to the variety of possible states, $d_{i m} w=n \cdot n$.

Computational complexity of solving systems of linear algebraic equations (1) in conjunction with the normalization condition

$$
\sum_{i=1}^{n} \pi_{i}
$$

grows rapidly along with an increase in problem dimensionality $[6,7]$.Herewith one should note that when solving lots of practical problems, their numerical solution will be insufficient. Problems of economics, reliability theory, structural and parametric synthesis of systems, management theory should provide for analytical relations that determine the dependence of the probability distribution of system states on the numerical values of their parameters [8-10]. The issue of obtaining such relations is particularly significant for the problems of analyzing multi-threaded systems. The conventional approach to its solution is to use the technology of enlarging states of the related Markov chain $[12,13]$.

\section{Analyzing known results}

The decomposition problem arising from states enlargement is implemented as follows. The entire set of possible system states is divided into subsets. At each iteration of solving problems, one of the subsets is allocated, but the states of other subsets are enlarged. The resulting system of states is processed. Let's write the related formal relations.

The initial set of states $E=\{1,2, \ldots, n\}$ is divided into $m$ subsets

$$
E=\left\{E_{1}, E_{2}, \ldots, E_{m}\right\}, \bigcup_{k=1}^{m} E_{k}=E, E_{k_{1}} \cap E_{k_{2}}=\varnothing .
$$

The states of each subset are renumbered:

$$
\begin{gathered}
E_{1}=\left\{i_{11}, i_{12}, . ., i_{1 n_{1}}\right\}, E_{2}=\left\{i_{21}, i_{22}, . ., i_{2 n_{2}}\right\}, \\
E_{m}=\left\{i_{m 1}, i_{m 2}, . ., i_{m n_{m}}\right\} .
\end{gathered}
$$

Let's enter the related (3) initial distribution of states

$$
\pi^{(0)}=\left(\pi_{i_{11}}^{(0)}, \ldots, \pi_{i_{1 n_{1}}}^{(0)}\right), \ldots,\left(\pi_{i_{m_{1}}}^{(0)}, \ldots, \pi_{i_{m n_{m}}}^{(0)}\right) .
$$

At the first iteration of the problem solving procedure let's allocate the first $E_{l}$ set, and enlarge states of the remaining subsets by assigning them the related initial values of stay probabilities. Thus the resulting set of states probabilities is as follows:

$$
\begin{gathered}
\pi_{i_{0}}^{(0)}=\left(\pi_{i_{11}}^{(0)}, \pi_{i_{12}}^{(0)}, \ldots, \pi_{i_{1 n_{1}}}^{(0)}\right) ; \pi_{i_{k}}^{(0)} ; k=2,3, \ldots, m ; \\
\pi_{i_{k}}^{(0)}=\sum_{s=1}^{n_{k}} \pi_{i_{k s}} ; k=2,3, \ldots, m .
\end{gathered}
$$

To analyze the resulting system of states let's determine the transition probabilities.

The probabilities of transition from states of the allocated set to those of the same set remain equal to the original ones, that is $P_{i_{1} s_{1}, i_{1} s_{2}},\left(i_{s_{1}}, i_{s_{2}}\right) \epsilon E_{1}$.

The probability of transition from any $i_{I_{s}}$ state of the $E_{l}$ allocated subset to any $E_{k}$ enlarged state is equal to the sum of probabilities of transitions from this state to all the states of the enlarged state, that is

$$
P_{i_{1 s}}, i_{k}=\sum_{s_{2}=1}^{n_{k}} P_{i 1 s_{1}}, i_{k s_{2}}, s_{2}=1,2, \ldots, n_{k} .
$$

The probability of transition from any $E_{k}$ enlarged state to any of the $i_{l s}$ states of the $E_{l}$ allocated subset is 
equal to the sum of productions of probabilities of transitions from the $E_{k}$ states of subsets to $i_{l s}$ by the $\pi_{i k s}$ conditional probabilities of the system remaining in these states, that is

$$
P_{i k}, i_{1 s}=\sum_{s_{1}=1}^{n_{k}} P_{i k s}, i_{1 s} \cdot \pi_{i k s_{1}} / \sum_{s_{1}=1}^{n k} \pi_{i k s_{1}}, s=\overline{1, n_{1}} .
$$

Here the conditional probabilities of remaining in the $E_{k}$ states of the subset are assumed to be equal to $\pi_{i k s_{1}}=1 / n_{k}$.

Finally, the probability of transition from any enlarged $E_{k_{1}}$ state to some enlarged is $E_{k_{2}}$ state equals to the sum of probabilities of getting into $E_{k_{2}}$, each of which, in turn, is equal to the production of probabilities of transition from states $E_{k_{1}}$ to $E_{k_{2}}$ by the conditional probability of remaining in the proper $E_{k_{1}}$ state, that is

$$
P_{k_{1} k_{2}}=\sum_{s_{1}=1}^{n k_{1}} \sum_{s_{2}=1}^{n k_{2}} P_{i k_{1} s_{1}}, k_{2} s_{2} \frac{\pi_{i k_{1} s_{1}}}{\sum_{s_{1}=1}^{n k_{1}} \pi_{i k_{1} s_{1}}} .
$$

The transition probabilities calculated using formulas (5)-(7) make up the $W^{(1)}$ matrix, which is used to calculate probabilities of states within a $\pi^{(1)}=\left(\pi_{i 11}, \pi_{i 12}, . ., \pi_{i 1 n_{1}} ; \pi_{i 2}, \pi_{i 3}, \ldots, \pi_{i m}\right)$ set using a formula

$$
\pi^{(1)}=\pi^{(1)} W^{(1)} .
$$

At the second iteration, the states of the first subset are enlarged due to a group probability equal to the sum of probabilities obtained at the first iteration. The second subset slims down, but all subsequent subsets remain unchanged. The iteration cycle is repeated $m$ times. As a result, the first approximation to the desired set of probabilities of system states shall be obtained. This iterative cycle of $m$ steps must be repeated a required number of times. Stop criterion: the maximum value of the modulus of the probability differences of the same events within neighboring cycles should become less than the specified small number.

The given procedure ensures obtaining the desired probability distribution of the system states, however, the rate of its convergence is unpredictable and may be unacceptable for systems with a real number of states.

In this context, an issue of analyzing systems with a large number of possible states remains relevant, which initiates the continuation of studies.

Study objective: development of a decomposition analytical method for the study of multi-threaded queuing systems.

A feasible direction is the adaptation of the undoubtedly promising idea of decomposition to the design features of multi-threaded systems.

Basic material. Decomposition method for analyzing high-dimensional multi-threaded systems. Let's consider the technology of generating models of multi-threaded Markov queuing systems as applied to systems with failures.
The analysis of the simplest system, whose input receives a single customer thread, shall be carried out using a one-dimensional graph of states and transitions. Unless the intensity of the input thread is equal to $\lambda$, and the intensity of queuing is equal to $\mu$, then this graph for an $n$-channel system is as follows.
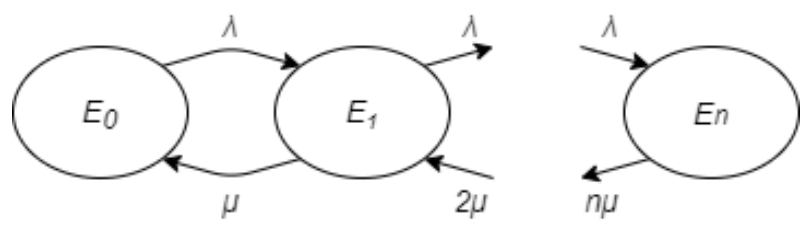

Fig. 1. A graph of states and transitions of a single-threaded system

Unless the queuing system receives two independent threads with proper values for the intensities of customer threads and their queuing $\left(\lambda_{1}, \mu_{1}\right)$, $\left(\lambda_{2}, \mu_{2}\right)$, where the $n_{1}$ channels are used for queuing the first customer thread and the $n_{2}$ channels for the second one, then the related two-dimensional transition graph is as follows
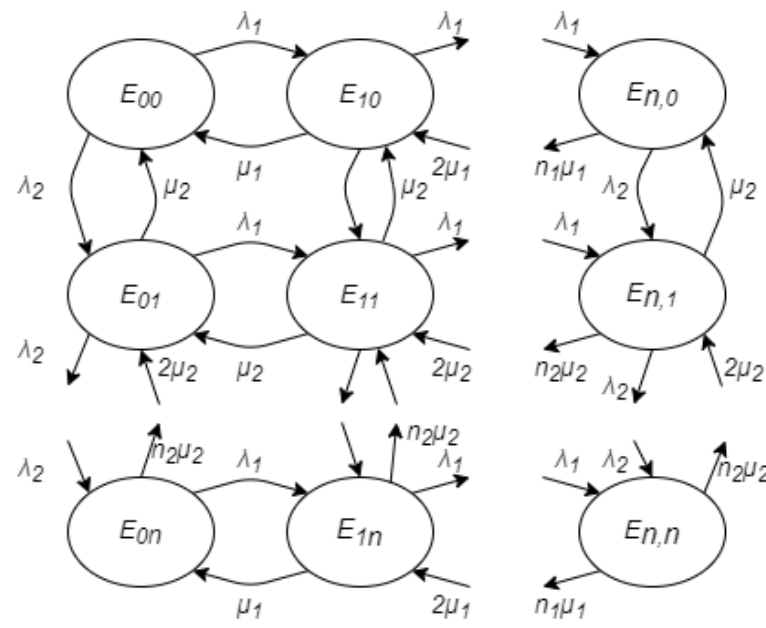

Fig. 2. A graph of states and transitions of a double-threaded system

The model of a triple-threaded queuing system with $\left(\lambda_{1}, \mu_{1}, n_{1}\right),\left(\lambda_{2}, \mu_{2}, n_{2}\right),\left(\lambda_{3}, \mu_{3}, n_{3}\right)$ parameters is a three-dimensional graph given in Fig. 3 .

The dimensionality of the problem to analyze multi-threaded systems is growing rapidly with an increase in the number of $m$ threads. For an $r$-threaded system, the total number of its possible states $N_{r}=\prod_{s=1}^{R} n_{s}$ which makes it really difficult to carry out studies.

Let's note the most important feature of the graph structure of multi-threaded queuing systems. The complete graph of a Nmulti-threaded dimensionality system can be naturally divided into a set of subgraphs of smaller dimensionality corresponding to different values of the number of channels engaged in customer queuing from the related threads. Herewith the subgraphs within sections for different values of the number of occupied channels of the selected thread differ from each other by these values only, which, of course, simplifies the study of the system. 


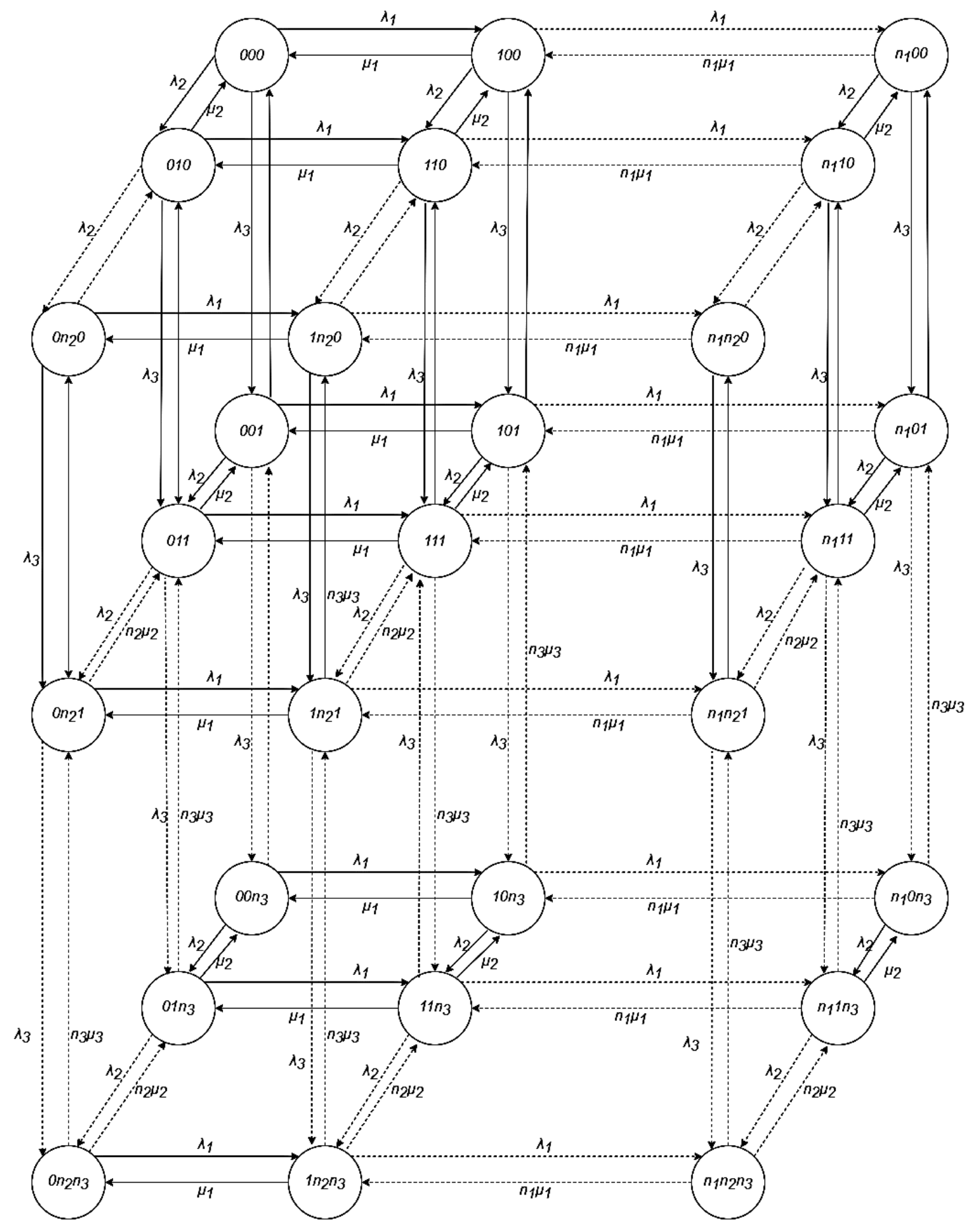

Fig. 3. A graph of states and transitions of a triple-threaded system

Let's consider the technology of analyzing highdimensional multi-threaded systems using decomposition procedures. The following three-stage technology for solving the generated issue is proposed.

The first stage assumes that according to the general principle of decomposition, the entire set of system states should be divided into a number of subsets $\left\{E_{1}, E_{2}, \ldots, E_{m}\right\}$. Herewith the $W$ transitions probability matrix is divided into the same number of submatrices $\left\{W_{1}, W_{2}, \ldots, W_{m}\right\}$. Each of arising subsets should be analyzed in a standard way. As a result of solving the related problems, a set of distributions of conditional probabilities of states shall be obtained.
The second stage assumes that the probabilities of transitions between subsets should be calculated, each of which is treated as an enlarged state. The distribution of states of the initial system is calculated using the probability vector of transitions between enlarged states.

The third stage assumes that a calculation of the desired set of probabilities of the initial analyzed system states is carried out.

Let's consider the technology of applying the proposed method to a specific example. Let the triplethreaded queuing system with the two channels for each thread be analyzed.

A graph for system states and transitions is given in Fig. 4. 


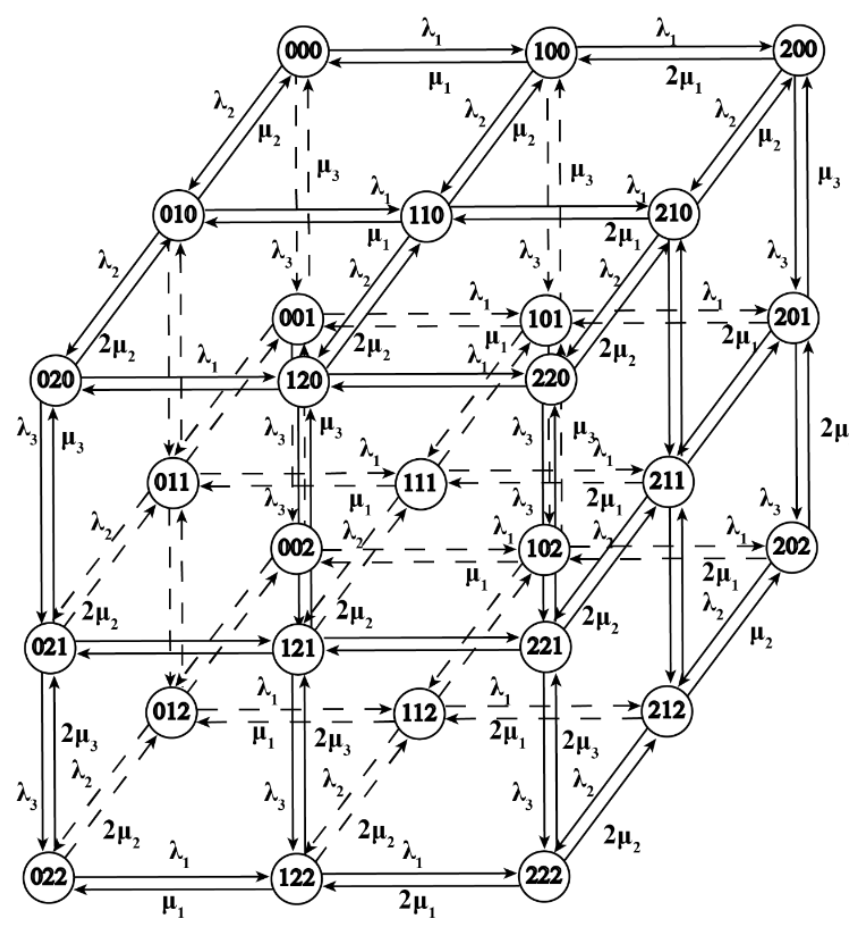

Fig. 4. Graph of states and transitions in a triple-threaded Markov system $\left(\lambda_{1}, \mu_{1}, n_{1}\right),\left(\lambda_{2}, \mu_{2}, n_{2}\right),\left(\lambda_{3}, \mu_{3}, n_{3}\right)$.

Stage 1. The entire set of states of the Einitial graph is divided into three $E_{0}, E_{1}, E_{2}$ subsets by the number of third thread channels engaged in queuing. The related subgraphs of states and transitions are shown in Fig. 5 to Fig. 7.

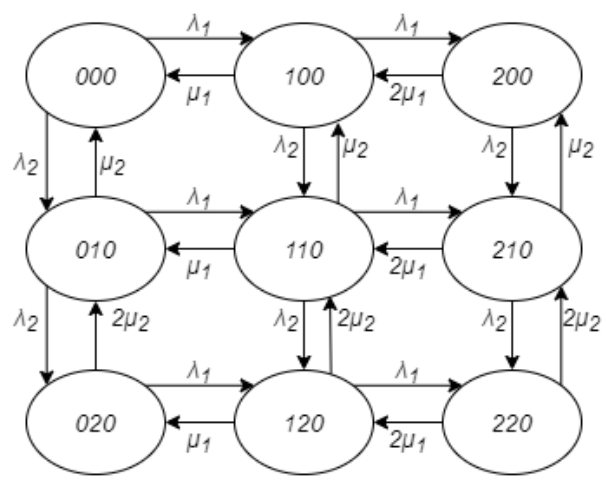

Fig. 5. A subgraph of states and transitions in a double-threaded system $\left(\lambda_{1}, \mu_{1}\right),\left(\lambda_{2}, \mu_{2}\right)$ with a fixed number of engaged channels queuing customer of the third thread equal to zero

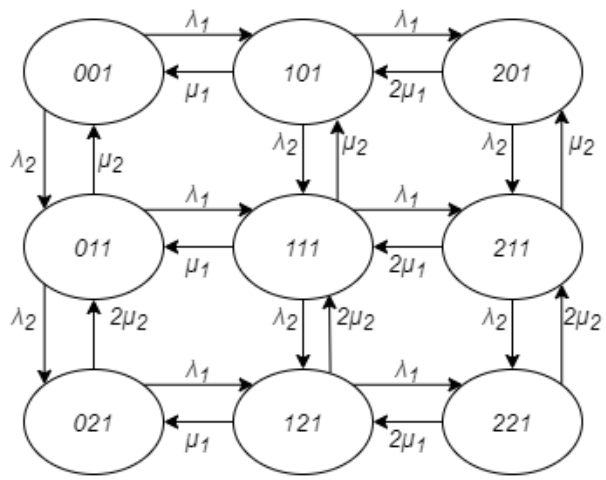

Fig. 6. A subgraph of states and transitions in a double-threaded system $\left(\lambda_{1}, \mu_{1}\right),\left(\lambda_{2}, \mu_{2}\right)$ with a fixed number of engaged channels queuing customer of the third thread equal to figure of one

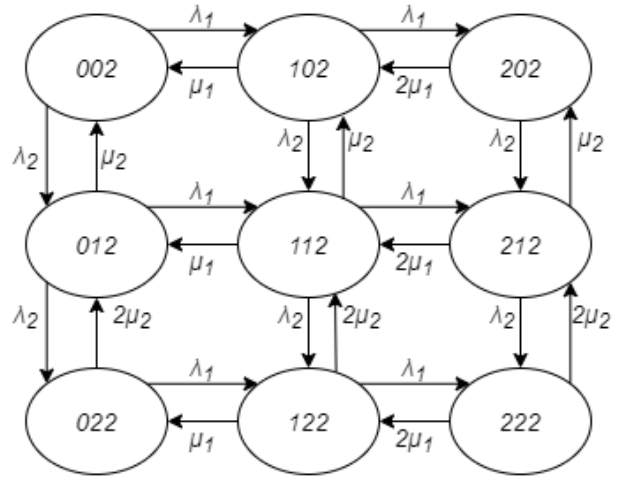

Fig. 7. A subgraph of states and transitions in a double-threaded system $\left(\lambda_{1}, \mu_{1}\right),\left(\lambda_{2}, \mu_{2}\right)$ with a fixed number of engaged channels queuing customer of the third thread equal to figure of two

When comparing these figures, it is clear that the transition system structure in all three subgraphs is identical. Thus, to search for the distributions of states, it is enough to solve only a single analysis problem for any of the subgraphs. Let's analyze the $E_{0}$ subgraph. This graph contains nine states $\{0,0 ; 1,0 ; 2,0 ; 0,1 ; 1,1$; $2,1 ; 0,2 ; 1,2 ; 2 ; 2\}$. In order to simplify the input, the third index corresponding to the number of engaged channels queuing customer of the third thread is omitted here. The related matrix of $S_{0}$ transition intensities for the $E_{0}$ subgraph is as follows

$$
S_{0}=\left(\begin{array}{ccccccccc}
0 & \lambda_{1} & 0 & \lambda_{2} & 0 & 0 & 0 & 0 & 0 \\
\mu_{1} & 0 & \lambda_{1} & 0 & \lambda_{2} & 0 & 0 & 0 & 0 \\
0 & 2 \mu_{1} & 0 & 0 & 0 & \lambda_{2} & 0 & 0 & 0 \\
\mu_{2} & 0 & 0 & 0 & \lambda_{1} & 0 & \lambda_{2} & 0 & 0 \\
0 & \mu_{2} & 0 & \mu_{1} & 0 & \lambda_{1} & 0 & \lambda_{2} & 0 \\
0 & 0 & \mu_{2} & 0 & 2 \mu_{1} & 0 & 0 & 0 & \lambda_{2} \\
0 & 0 & 0 & \mu_{2} & 0 & 0 & 0 & \lambda_{1} & 0 \\
0 & 0 & 0 & 0 & \mu_{2} & 0 & \mu_{1} & 0 & \lambda_{1} \\
0 & 0 & 0 & 0 & 0 & \mu_{2} & 0 & 2 \mu_{1} & 0
\end{array}\right) .
$$

This matrix of transition intensities is easily transformed into a matrix of $P=\left(p_{i j}\right)$ transition probabilities, using which a system of linear algebraic equations is formed with respect to the vector of conditional probabilities of states

$$
\pi_{0}=\left(\pi_{00}, \pi_{10}, \pi_{20} ; \pi_{01}, \pi_{11}, \pi_{21} ; \pi_{02}, \pi_{12}, \pi_{22}\right) .
$$

This system, supplemented by the normalization condition, is as follows

$$
\begin{gathered}
\pi_{0}=\pi_{0} P, \\
\sum_{i_{1}=0 i_{2}=0}^{2} \sum_{i_{1} i_{2}}^{2}=1 .
\end{gathered}
$$

The numerical solution of this system can be easily obtained. However, the analytical solution, even for the resulting simple system, requires tedious transformations. At the same time, to analyze the system described by the $E_{0}$ (or $E_{1}$, or $E_{2}$ ) subgraph, the ideas of decomposition can be used once again. The $E_{0}$ states subset is divided into three $E_{00}, E_{01}, E_{02}$ subsets as follows: 


$$
\begin{gathered}
E_{00}=\{0,0 ; 1,0 ; 2,0\}, \quad E_{01}=\{0,1 ; 1,1 ; 2,1\}, \\
E_{02}=\{0,2 ; 1,2 ; 2,2\} .
\end{gathered}
$$

The corresponding sub-subgraphs are of the following identical form

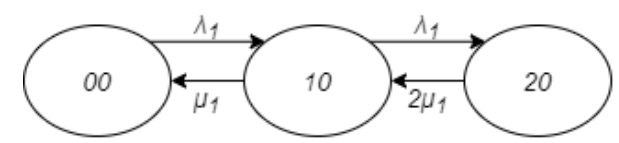

Fig. 8. A sub-subgraph of the E0 subgraph of states and transitions

A vector of $\left(\hat{\pi}_{00}, \hat{\pi}_{10}, \hat{\pi}_{20}\right) \quad$ conditional probabilities of states is entered in the $E_{0}$ sub-subgraph. Considering the structure of this sub-subgraph the components of this vector are calculated using the Erlang formula

$$
\hat{\pi}_{i 0}=\frac{\left(\lambda_{1} / \mu_{1}\right)^{i} / i !}{\sum_{i=0}^{2}\left(\lambda_{1} / \mu_{1}\right)^{i} / i !}, i=0,1,2
$$

It is clear that the same relations determine the distributions of states for the $E_{01}$ and $E_{02}$ sub-subgraphs, that is

$$
\hat{\pi}_{i 1}=\hat{\pi}_{i 2}=\frac{\left(\lambda_{1} / \mu_{1}\right)^{i} / i !}{\sum_{i=0}^{2}\left(\lambda_{1} / \mu_{1}\right)^{i} / i !}, i=0,1,2 .
$$

The next step is to calculate the probabilities of transition between the $E_{00}, E_{01}, E_{02}$ sub-subsets in accordance with the $E_{0}$ subgraph structure:

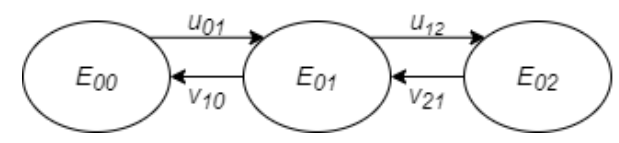

Fig. 9. The $E_{0}$ subgraph structure

The relations for calculating probabilities of transition are obtained using a detailed structure of the $E_{0}$ subgraph (Fig. 5)

$$
\begin{aligned}
u_{01} & =\hat{\pi}_{00} \lambda_{2}+\hat{\pi}_{10} \lambda_{2}+\hat{\pi}_{20} \lambda_{2}= \\
& =\lambda_{2}\left(\hat{\pi}_{00}+\hat{\pi}_{10}+\hat{\pi}_{20}\right)=\lambda_{2}, \\
u_{12} & =\hat{\pi}_{01} \lambda_{2}+\hat{\pi}_{11} \lambda_{2}+\hat{\pi}_{21} \lambda_{2}= \\
& =\lambda_{2}\left(\hat{\pi}_{01}+\hat{\pi}_{11}+\hat{\pi}_{21}\right)=\lambda_{2}, \\
v_{10} & =\hat{\pi}_{01} \mu_{2}+\hat{\pi}_{11} \mu_{2}+\hat{\pi}_{21} \mu_{2}= \\
& =\mu_{2}\left(\hat{\pi}_{01}+\hat{\pi}_{11}+\hat{\pi}_{21}\right)=\mu_{2}, \\
v_{21} & =\hat{\pi}_{02} 2 \mu_{2}+\hat{\pi}_{12} 2 \mu_{2}+\hat{\pi}_{22} 2 \mu_{2}= \\
& =2 \mu_{2}\left(\hat{\pi}_{02}+\hat{\pi}_{12}+\hat{\pi}_{22}\right)=2 \mu_{2} .
\end{aligned}
$$

Accordingly, the $E_{0}$ structure, given in Fig. 9, acquires the following form available for analysis

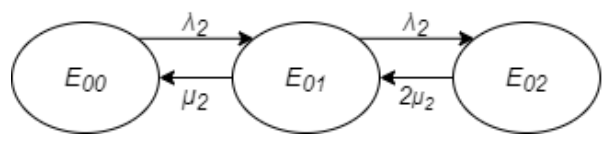

Fig. 10. The $E_{0}$ subgraph structure

The obtained (10)-(12) relations allow to calculate the distribution of the system remaining in the states of the $E_{00}, E_{01}, E_{02}$ subgraphs. Let's enter the corresponding $t_{0}=\left(t_{00}, t_{01}, t_{02}\right)$ vector, whose components are determined using the Erlang formulas:

$$
t_{0 j}=\frac{\left(\lambda_{2} / \mu_{2}\right)^{j} / j !}{\sum_{j=0}^{2}\left(\lambda_{2} / \mu_{2}\right)^{j} / j !}, j=0,1,2 .
$$

Then the distribution of states for the $E_{0}$ subgraph is as follows.

$$
\begin{gathered}
\pi_{00}=\hat{\pi}_{00} t_{00} ; \pi_{10}=\hat{\pi}_{10} t_{00} ; \pi_{20}=\hat{\pi}_{20} t_{00} ; \\
\pi_{01}=\hat{\pi}_{01} t_{01} ; \pi_{11}=\hat{\pi}_{11} t_{01} ; \pi_{21}=\hat{\pi}_{21} t_{01} ; \\
\pi_{02}=\hat{\pi}_{02} t_{02} ; \pi_{12}=\hat{\pi}_{12} t_{01} ; \pi_{22}=\hat{\pi}_{22} t_{02} ; \\
\pi_{i j}=\frac{\left(\lambda_{1} / \mu_{1}\right)^{j} / j !}{\sum_{j=0}^{2}\left(\lambda_{1} / \mu_{1}\right)^{j} / j !} \cdot \frac{\left(\lambda_{2} / \mu_{2}\right)^{j} / j !}{\sum_{j=0}^{2}\left(\lambda_{2} / \mu_{2}\right)^{j} / j !} .
\end{gathered}
$$

It is clear that the analysis carried out for the $E_{0}$ subgraph can be repeated for $E_{1}$ and $E_{2}$ subgraphs as well. In addition, the same distributions as above can be obtained when calculating the probabilities of transitions between $E_{0}, E_{1}, E_{2}$. As one can easily see in Fig. 4 these distributions assume that the subgraph structure of the initial graph of states and transitions has the form given in Fig. 11.

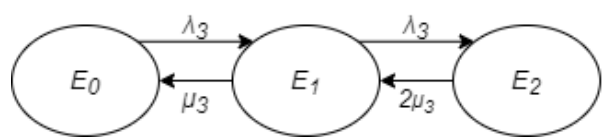

Fig. 11. The subgraph structure of the Egraph of states and transitions of systems

Let's enter the $W=\left(W_{0}, W_{1}, W_{2}\right)$ vector of probabilities of the system remaining within $E_{0}, E_{1}, E_{2}$ subsets. As before, the components of this vector are determined using the Erlang formulas:

$$
W_{k}=\frac{\left(\lambda_{3} / \mu_{3}\right)^{k} / k !}{\sum_{k=0}^{2}\left(\lambda_{3} / \mu_{3}\right)^{k} / k !}, k=0,1,2 .
$$

Now, considering remarks from above and based on (15), (16) let's write the final relations determining the distribution of states of the analyzed triple-threaded Markov system having two queuing channels for each thread.

This distribution is as follows:

$$
\pi_{i j k}=\left(\frac{\left(\lambda_{1} / \mu_{1}\right)^{i} / i !}{\sum_{i=0}^{2}\left(\lambda_{1} / \mu_{1}\right)^{i} / i !}\right) \times
$$

$$
\begin{gathered}
\times\left(\frac{\left(\lambda_{2} / \mu_{2}\right)^{j} / j !}{\sum_{j=0}^{2}\left(\lambda_{2} / \mu_{2}\right)^{j} / j !}\right)\left(\frac{\left(\lambda_{3} / \mu_{3}\right)^{k} / k !}{\sum_{k=0}^{2}\left(\lambda_{3} / \mu_{3}\right)^{k} / k !}\right), \\
i=0,1,2 ; j=0,1,2 ; k=0,1,2 .
\end{gathered}
$$

The problem is solved.

It is clear that the proposed technique easily applies to the case of analyzing a queuing system, the input of which receives a superposition of $m$ threads with $\left(\lambda_{i}, \mu_{i}\right), i=1,2, \ldots m$ parameters. Customer entering 
input are queued by a system that has $n_{i}$ channels for the related $i$-th thread $I=1,2, \ldots m$. Let's enter a vector $\left(i_{1}, i_{2}, \ldots, i_{m}\right)$, the $i_{s}$ component of which determines the number of channels engaged in customer queuing of the $s$-th thread, $s=1,2, \ldots, m$.

Then, similar to (17), the distribution of states of the system is determined by the following relations:

$$
\begin{gathered}
\pi_{i_{1} i_{2} \ldots i_{m}}=\left(\frac{\left(\lambda_{1} / \mu_{1}\right)^{i_{1}} / i_{1} !}{\sum_{i_{1}=0}^{2}\left(\lambda_{1} / \mu_{1}\right)^{i_{1}} / i_{1} !}\right) \times \\
\times\left(\frac{\left(\lambda_{2} / \mu_{2}\right)^{i_{2}} / i_{2} !}{\sum_{i_{2}=0}^{2}\left(\lambda_{2} / \mu_{2}\right)^{i_{2}} / i_{2} !}\right) \ldots\left(\frac{\left(\lambda_{m} / \mu_{m}\right)^{i_{m}} / i_{m} !}{\sum_{i_{m}=0}^{2}\left(\lambda_{m} / \mu_{m}\right)^{i_{m} / i_{m} !}}\right)= \\
=\prod_{s=1}^{m}\left(\frac{\left(\lambda_{s} / \mu_{s 1}\right)^{i_{s}} / i_{s} !}{\sum_{i_{s}=0}^{2}\left(\lambda_{s} / \mu_{s 1}\right)^{i_{s}} / i_{s} !}\right) .
\end{gathered}
$$
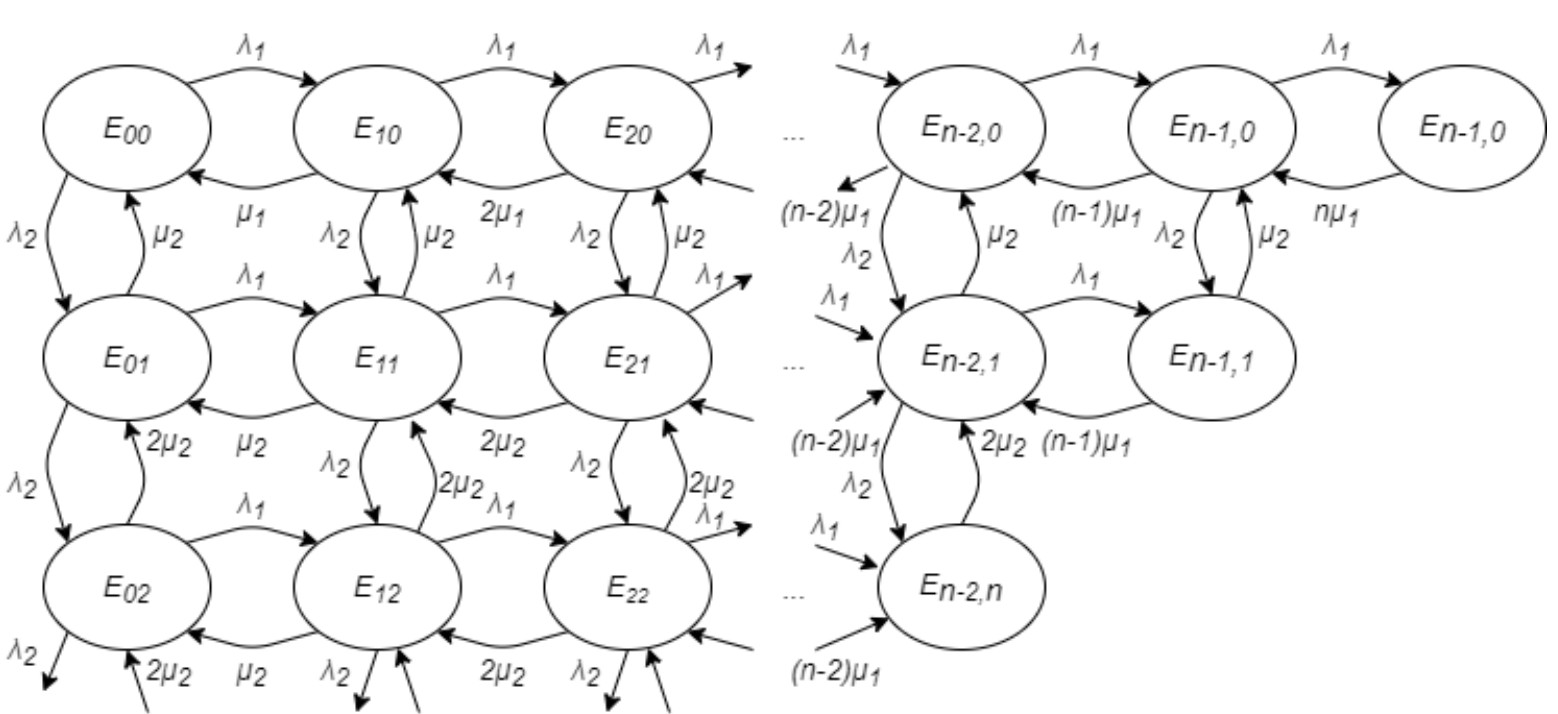

The relative simplicity of the result obtained is due to the use of a rather hard limiting: a number of channels for customer queuing of each thread is fixed. The removal of this customer, which shall occur unless each channel is adapted to customer queuing from any thread, complicates the situation to some extent.

Let's consider a method for solving the problem arising in this case on a concrete example of analyzing a double-threaded system with $\left(\begin{array}{lll}\lambda_{1}, & \mu & 1\end{array}\right),\left(\begin{array}{llll}\lambda & 2, & \mu_{2}\end{array}\right)$ parameters and a total number of $n$ queuing channels. Such graph of states and transitions is given in Fig. 12.

Under the given decomposition technology, let's divide the entire set of states into $E_{0}, E_{l}, \ldots, E_{k}, \ldots, E_{n-l}$, $E_{n}$ subsets by the number of channels engaged in customer queuing of the second thread.

The related graph of states and transitions is given in Fig. 13.

Let's calculate the conditional distribution of states for each of the $E_{0}, E_{1}, \ldots, E_{n}$ subsets using the Erlang formulas.

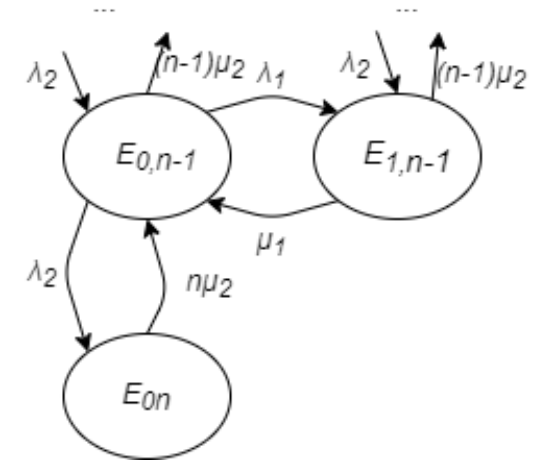

Fig. 12. A graph of states and transitions of a double-threaded system with $n$ queuing channels
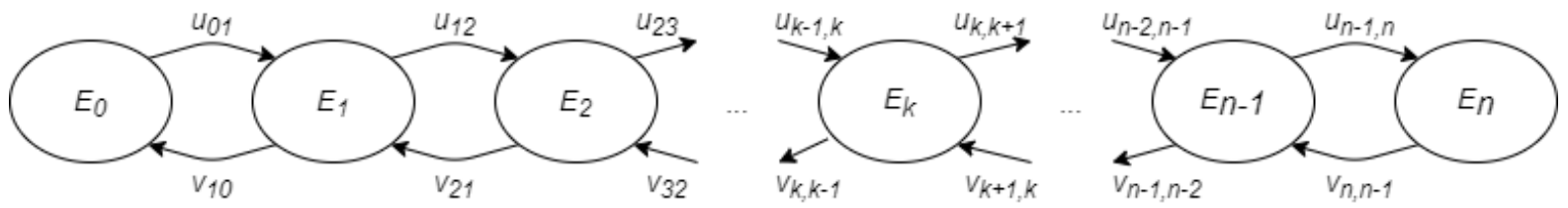

Fig. 13. A graph of states and transitions for a grouped set of states 
The conditional distribution of states for $E_{0}$ is as follows.

$$
\hat{\pi}_{i 0}=\frac{\left(\lambda_{1} / \mu_{1}\right)^{i} / i !}{\sum_{i=0}^{n}\left(\lambda_{1} / \mu_{1}\right)^{i} / i !}, i=0,1,2, \ldots, n .
$$

The conditional distribution of states for $E_{l}$ :

$$
\hat{\pi}_{i 1}=\frac{\left(\lambda_{1} / \mu_{1}\right)^{i} / i !}{\sum_{i=0}^{n-1}\left(\lambda_{1} / \mu_{1}\right)^{i} / i !}, i=0,1,2, \ldots, n-1 .
$$

The conditional distribution of states for $E_{k}$ :

$$
\hat{\pi}_{i k}=\frac{\left(\lambda_{1} / \mu_{1}\right)^{i} / i !}{\sum_{i=0}^{n-k}\left(\lambda_{1} / \mu_{1}\right)^{i} / i !}, i=0,1,2, \ldots, n-k .
$$

The conditional distribution of states for $E_{n-1}$ :

$$
\hat{\pi}_{i n-1}=\frac{\left(\lambda_{1} / \mu_{1}\right)^{i} / i !}{\sum_{i=0}^{1}\left(\lambda_{1} / \mu_{1}\right)^{i} / i !}=\frac{\left(\lambda_{1} / \mu_{1}\right)^{i} / i !}{1+\lambda_{1} / \mu_{1}}, i=0,1 \text {. }
$$

The conditional distribution of states for $E_{0}$ :

$$
\hat{\pi}_{i n}=1 \text {. }
$$

Now let's calculate a set of transition probabilities between subsets:

$$
\begin{gathered}
u_{01}=\hat{\pi}_{00} \lambda_{2}+\hat{\pi}_{10} \lambda_{2}+\ldots+\hat{\pi}_{n-1,0} \lambda_{2}= \\
=\lambda_{2} \sum_{i=0}^{n-1} \hat{\pi}_{i 0}, \\
v_{10}=\hat{\pi}_{01} \mu_{2}+\hat{\pi}_{11} \mu_{2}+\ldots+\hat{\pi}_{n-1,1} \mu_{2}=\mu_{2} \sum_{i=0}^{n-1} \hat{\pi}_{i 1}, \\
u_{12}=\hat{\pi}_{01} \lambda_{2}+\hat{\pi}_{11} \lambda_{2}+\ldots+\hat{\pi}_{n-1,2} \lambda_{2}=\lambda_{2} \sum_{i=0}^{n-2} \hat{\pi}_{i 2}, \\
v_{21}=\hat{\pi}_{02} 2 \mu_{2}+\hat{\pi}_{12} 2 \mu_{2}+\ldots+\hat{\pi}_{n-1,2} 2 \mu_{2}=2 \mu_{2} \sum_{i=0}^{n-2} \hat{\pi}_{i 2}, \\
u_{\kappa-1, \kappa}=\hat{\pi}_{0 \kappa-1} \lambda_{2}+\hat{\pi}_{1 k-1} \lambda_{2}+\ldots+\hat{\pi}_{n-k+1, k-1} \lambda_{2}= \\
=\lambda_{2} \sum_{i=0}^{n-k+1} \hat{\pi}_{i k-1}, \\
v_{n, n-1}=\hat{\pi}_{0 n} . n \mu_{2} . \\
u_{n-1, n}=\hat{\pi}_{0 n-1} \lambda_{2}+\hat{\pi}_{1 n-1} \sum_{i=0}^{n-2} \hat{\pi}_{i n-1}, \ldots+\hat{\pi}_{n-1,2} \lambda_{2}= \\
=k \mu_{2} \sum_{i=0}^{n-k} \hat{\pi}_{i k}, \\
v_{0 k} k \mu_{2}+\hat{\pi}_{1 k} k \mu_{2}+\ldots+\hat{\pi}_{n-k, k} k \mu_{2}=
\end{gathered}
$$

The resulting set of transition probabilities between subsets of states allows to find out the distribution of related probabilities.
Let's make up a system of Kolmogorov equations with respect to the $\mathrm{P} 0, \mathrm{P} 1, \ldots, \mathrm{Pn}$ probabilities of the system remaining within $\mathrm{E} 0, \mathrm{E} 1, \mathrm{E} 2, \ldots, \mathrm{En}$ subsets, we have

$$
\begin{gathered}
-u_{01} P_{0}+v_{10} P_{1}=0, \\
u_{01} P_{0}+v_{21} P_{2}-P_{1}\left(u_{12}+v_{10}\right)=0, \\
u_{12} P_{1}+v_{32} P_{3}-P_{2}\left(u_{23}+v_{21}\right)=0, \\
u_{k-1, k} P_{k-1}+v_{k+1, k} P_{k+1}- \\
-P_{k}\left(u_{k, k+1}+v_{k, k-1}\right)=0, \\
\cdots \\
u_{n-2, n-1} P_{n-2}+v_{n, n-1} P_{n}- \\
-P_{n-1}\left(u_{n-1, n}+v_{n-1, n-2}\right)=0, \\
u_{n-1, n} P_{n-1}+v_{n, n-1} P_{n}=0 .
\end{gathered}
$$

In order to simplify the analytical description of the system of algebraic equations (25), let's enter additional variables

$$
y_{k}=u_{k-1, k} P_{k-1}-v_{k, k-1} P_{k}, k=1,2, \ldots, n .
$$

By substituting (26) into (25), we obtain

$$
\begin{gathered}
y_{1}=0, \\
y_{1}-y_{2}=0, \\
y_{2}-y_{3}=0, \\
\ldots \\
y_{k}-y_{k+1}=0, \\
\ldots \\
y_{n-1}-y_{n}=0, \\
y_{n}=0 .
\end{gathered}
$$

Therefore

$$
y_{1}=y_{2}=\ldots=y_{k}=\ldots=y_{n}=0
$$

Thus

$$
y_{k}=u_{k-1, k} P_{k-1}-v_{k, k-1} P_{k}=0 .
$$

Equation (28) sets the recurrence relation

$$
P_{k}=\frac{u_{k-1, k}}{v_{k, k-1}} P_{k-1}, k=1,2, \ldots, n .
$$

Therefore we obtain

$$
\begin{gathered}
P_{1}=\frac{u_{01}}{v_{10}} P_{0}, \\
P_{2}=\frac{u_{12}}{v_{21}} P_{1}, \\
\ldots \\
P_{k}=\frac{u_{k-1, k}}{v_{k, k-1}} P_{k-1}, \\
\ldots \\
P_{n}=\frac{u_{n-1, n}}{v_{n, n-1}} P_{n-1 .}
\end{gathered}
$$


Using a sequential system of substitutions of the subsequent relation from (30) to the previous one, let's express all the probabilities obtained by means of $P_{0}$. We have

$$
\begin{gathered}
P_{2}=\frac{u_{12} u_{01}}{v_{10} v_{21}} P_{0}=\frac{\prod_{s=1}^{2} u_{s-1, s}}{\prod_{s=1}^{2} v_{s, s-1}}, \\
\ldots \\
P_{k}=\frac{u_{01} u_{12} \ldots u_{k-1, k}}{v_{10} v_{21} \ldots v_{k, k-1}} P_{0}= \\
\frac{\prod_{s=1}^{k} u_{s-1, s}}{\prod_{s=1}^{k} P_{s, s-1}, k=1,2, \ldots, n .} \\
P_{n}=\frac{1}{\prod_{s=1}^{n} u_{s-1, s}} P_{0.1} .
\end{gathered}
$$

To search for $P_{0}$, we use the normalization condition:

$$
\sum_{k=0}^{n} P_{k}=\left(1+\sum_{k=1}^{n} \frac{\prod_{s=1}^{k} u_{s-1, s}}{\prod_{s=1}^{k} v_{s, s-1}}\right) P_{0}=1 .
$$

Therefore

$$
P_{0}=\frac{1}{1+\sum_{k=1}^{n} \frac{\prod_{s=1}^{k} u_{s-1, s}}{\prod_{s=1}^{k} v_{s, s-1}}} .
$$

Then

$$
P_{k}=\frac{\frac{\prod_{s=1}^{k} u_{s-1, s}}{\prod_{s=1}^{k} v_{s, s-1}}}{1+\sum_{k=1}^{n} \frac{\prod_{s=1}^{k} u_{s-1, s}}{\prod_{s=1}^{k} v_{s, s-1}}}, k=0,1,2, \ldots, n .
$$

Now, combining the (19)-(22), (24), (32) relations, let 's write the unconditional probability of the $E_{i k}$ state
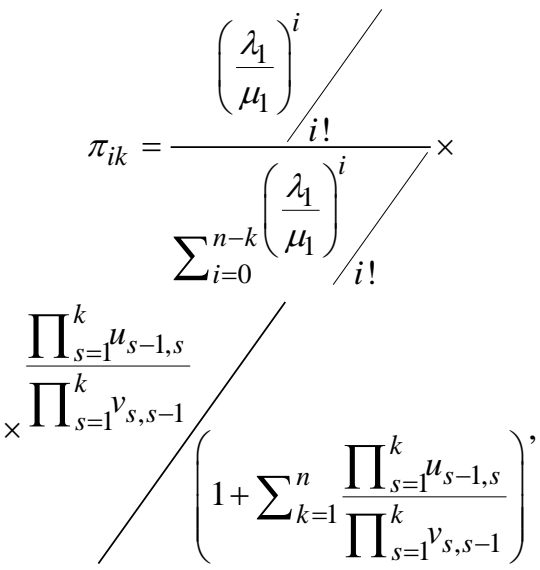

$i=0,1,2, \ldots, n ; k=0,1,2, \ldots, n ; i+k \leq n$.

The problem solution is completed.

The principal advantage of the proposed method of analyzing high-dimensional systems is to reduce the solutions of initially complex problems to a sequence of significantly simpler ones. Herewith, the method ensures an accurate solution of the problem. The further studies direction: spreading the proposed approach for the analysis of multi-threaded systems with thread priorities, whose relative importance is estimated by the pair-wise comparison method [14].

\section{Conclusions}

1. A method of analytical solution of the problem of analyzing high-dimensional Markov systems has been proposed. The computational pattern of the method implements the decomposition of the initial problem to a set of significantly simpler problems, the analytical solution of which is possible.

2. The principal advantage of the method is that the proposed technology can be established hierarchically. Herewith, the enlarged sets of states obtained following the first stage of the hierarchy can be divided into sub-subsets once again, unless required by their dimensionality.

\section{REFERENCES}

1. Volkova, V.N. and Denisov, A.A. (2006), Theory of systems, Higher School, Moscow, 511 p.

2. Boruga-Reed, A.T. (1969), Elements of the theory of Markov processes and their applications, Science, Moscow, $382 \mathrm{p}$.

3. Kemeny, J. and Snell, J. (1970), Finite Markov chains, Science, 264 p.

4. Schmidt, A.V. and Churyukin, V.A. (2015), "Markov models of economic systems", SU Bulletin, vol. 9, no. 3, pp. 100-105.

5. Ventetsl, E.S. and Ovcharov, L.A. (2000), Probability theory and its engineering-related applications, Higher School, Moscow, 318 p.

6. Ilyin, V.A. and Poznyak, E.G. (2004), Linear algebra, Physmathlit, Moscow, 280 p.

7. Verzhbitsky, V.M. (2009), Fundamentals of numerical methods, Higher School, Moscow, 840 p.

8. Sokolov, G.A. (2005), Probability theory. Controlled Markov chains in economics, Physmathlit, Moscow, 248 p.

9. Pugachev, V.S. (1962), Random functions theory and its application to automatic control problems, GIFML, Moscow, $384 \mathrm{p}$.

10. Timoshenkov, S.P. (2013), Fundamentals of reliability theory, MIET, Moscow, 284 p.

11. Kurenonkov, V.I., Volotsuev V.I. (2010), "Reliability of products and systems of rocket and space technology", Samara, 212 p.

12. Karpenko, V.V, and Yamen, Khazim (2016), "Decomposition technology of analyzing systems with a large number of states", Zb. Science. Papers of AFKNU, Vol. 2(17), pp. 97-99.

13. Raskin, L.G. (1997), "Markov chains analysis using phase enlargement of states", Science, technology, equipment, education, health, NTU KhPI, p. 28.

14. Raskin, L.G. and Seraya, O.V. (2003), "Formation of a scalar preference criterion based on the results of pair-wise comparisons", Bulletin of NTU KhPI, No. 6, pp. 63-68. 
Received (Надійшла) 15.10.2021

Accepted for publication (Прийнята до друку) 24.11.2021

\section{ВІдОМОстІ ПРО АВТОРів / АвOUT THE AUTHORS}

Раскін Лев Григорович - доктор технічних наук, професор, професор кафедри розподілених інформаційних систем і хмарних технологій, Національний технічний університет «Харківський політехнічний інститут», Харків, Україна;

Lev Raskin - Doctor of Technical Sciences, Professor, Professor of the Department of Distributed Information Systems and Cloud Technologies, National Technical University "Kharkiv Polytechnic Institute", Kharkiv, Ukraine;

e-mail: topology@ukr.net; ORCID: http://orcid.org/0000-0002-9015-4016.

Сухомлин Лариса Вадимівна - кандидат технічних наук, доцент, доцент кафедри менеджменту, Кременчуцький національний університет імені Михайла Остроградського, Кременчук, Україна;

Larysa Sukhomlyn - Candidate of Technical Sciences, Associate Professor, Associate Professor of the Department of Management, Kremenchuk Mikhail Ostrogradskiy National University, Kremenchuk, Ukraine; e-mail: lar.sukhomlyn@gmail.com; ORCID: https://orcid.org/0000-0001-9511-5932.

Сагайдачний Дмитро Олексійович - кандидат технічних наук, старший викладач, професор кафедри розподілених інформаційних систем і хмарних технологій, Національний технічний університет «ХПІ», Харків, Україна;

Dmytro Sagaidachny - Candidate of Technical Sciences, senior lecturer, Professor of the Department of Distributed Information Systems and Cloud Technologies, National Technical University "Kharkiv Polytechnic Institute", Kharkiv, Ukraine; e-mail: d.sagaydachny@gmail.com; ORCID: http://orcid.org/0000-0001-6901-6770.

Корсун Роман Олегович - аспірант кафедри розподілених інформаційних систем і хмарних технологій, Національний технічний університет «Харківський політехнічний інститут», Харків, Україна;

Roman Korsun - postgraduate student of the Department of Information Systems and Technologies,, National Technical University "Kharkiv Polytechnic Institute", Kharkiv, Ukraine;

e-mail: roman.korsun7@gmail.com; ORCID: https://orcid.org/0000-0002-1950-4263.

\section{Аналіз багатопоточних марківських систем \\ Л. Г. Раскін, Л. В. Сухомлин, Д. О. Сагайдачний, Р. О. Корсун}

Анотація. Відомі технології аналізу марківських систем використовують добре працюючий математичний апарат, що спирається на обчислювальну реалізацію основної марківської властивості. Виникаючі при цьому системи лінійних алгебраїчних рівнянь легко вирішуються чисельно. Разом з тим, при вирішенні багатьох практичних завдань цього чисельного рішення недостатньо. Наприклад, у задачах структурного та параметричного синтезу систем, а також у завданнях управління. У цих завданнях необхідно отримати аналітичні співвідношення, що описують залежність значень ймовірностей станів аналізованої системи з чисельними значеннями ії параметрів. Складність аналітичного розв'язання відповідних систем лінійних алгебраїчних рівнянь швидко зростає зі збільшенням розмірності системи. Саме цей феномен проявляється особливо демонстративно під час аналізу багатопотокових систем масового обслуговування. Відповідно до цього мета роботи - розробка ефективного обчислювального методу отримання аналітичних співвідношень, які забезпечують можливість аналізу марківських систем високої розмірності. У роботі для аналізу таких систем розроблено декомпозиційний метод, заснований на ідеї фазового укрупнення станів системи. Запропонований та обгрунтований метод дозволяє отримати аналітичні співвідношення для розрахунку розподілу ймовірностей станів марківських систем. Метод може бути ефективно застосований для вирішення завдань аналізу та управління в марківських системах високої розмірності. Розглянуто приклад.

Ключові слова: багатопотокові системи обслуговування; висока розмірність; декомпозиційний метод укрупнення станів.

\section{АНАЛИЗ МНОГОПОТОКОВЫХ МАРКОВСКИХ СИСТЕМ}

\section{Л. Г. Раскин, Л. В. Сухомлин, Д. О. Сагайдачный, Р. О. Корсун}

Аннотация. Известные технологии анализа марковских систем используют хорошо работающий математический аппарат, опирающийся на вычислительную реализацию основополагающего марковского свойства. Возникающие при этом системы линейных алгебраических уравнений легко решаются численно. Вместе с тем, при решении очень многих практических задач этого численного решения недостаточно. Например, в задачах структурного и параметрического синтеза систем, а также в задачах управления. В этих задачах необходимо получить аналитические соотношения, описывающие зависимости значений вероятностей состояний анализируемой системы с численными значениями её параметров. Сложность аналитического решения соответствующих систем линейных алгебраических уравнений быстро растет с увеличением размерности системы. Именно этот феномен проявляется в особенности демонстративно при анализе многопотоковых систем массового обслуживания. В соответствии с этим цель работы разработка эффективного вычислительного метода получения аналитических соотношений, обеспечивающих возможность анализа марковских систем высокой размерности. В работе для анализа таких систем разработан декомпозиционный метод, основанный на идее фазового укрупнения состояний системы. Предложенный и обоснованный метод позволяет получить аналитические соотношения для расчета распределения вероятностей состояний марковских систем. Метод может быть эффективно применен для решения задач анализа и управления в марковских системах высокой размерности. Рассмотрен пример.

Ключевые слова: многопотоковые системы обслуживания; высокая размерность; декомпозиционный метод укрупнения состояний. 